\title{
ANALISIS FAKTOR-FAKTOR YANG MENYEBABKAN KREDIT MACET PADA LEMBAGA PERKREDITAN DESA (LPD) DI KECAMATAN X
}

\author{
M. Rudi Irwansyah ${ }^{1}$, I Putu Arya Dharmayasa ${ }^{2}$ \\ Jurusan Pendidikan Ekonomi \\ Universitas Pendidikan Ganesha \\ Singaraja, Indonesia
}

e-mail: rudi.irwansyah@undiksha.ac.id ${ }^{1}, \underline{\text { aryadarmayasa4@gmail.com² }}$

\begin{abstract}
Abstrak
Penelitian ini bertujuan untuk memperoleh temuan deskriptif mengenai kredit macet, faktorfaktor yang menyebabkan kredit macet, dan faktor yang paling dominan menyebabkan kredit macet pada LPD di Kecamatan X. Penelitian ini adalah penelitian yang menggunakan jenis atau bentuk penelitian verifikasi dengan metode survei. Pengumpulan data dalam penelitian ini dilakukan dengan metode dokumentasi, wawancara, dan kuesioner. Data dianalisis dengan analisis deskriptif dan faktor.Hasil penelitian ini menunjukkan bahwa (1) Kredit macet pada LPD di Kecamatan X mengalami kenaikan dari Tahun 2014 sampai tahun 2016 dengan rata-rata kenaikan $488,27 \%$ pada tahun 2008 dan $19,80 \%$ pada tahun 2016, (2) Faktor-faktor yang menyebabkan kredit macet pada LPD di Kecamatan X adalah faktor Intern yang terdiri dari kelemahan administrasi dan kelemahan kualitas sumber daya manusia serta faktor ekstern yaitu faktor debitur, (3) Faktor yang paling dominan menyebabkan kredit macet adalah kelemahan dalam dokumentasi kredit merupakan faktor intern yang paling dominan menyebabkan kredit macet dan kecerobohan debitur merupakan faktor ekstern yang paling dominan menyebabkan kredit macet pada LPD di Kecamatan X
\end{abstract}

Kata Kunci : Kredit macet, Lembaga Perkreditan Desa,

\begin{abstract}
This study aims to obtain descriptive findings on promblem loans, factors that affect problem loans, and the most dominant factors affect problem loans in LPDs in District X. This research is a study that uses the type or form of verification research by survey method. Data collection in this research is done by documentation method, interview, and questionnaire. Data were analyzed by descriptive and factor analysis. The results of this study indicate that (1) problem debts in LPDs in Kecamatan X increased from 2014 to 2016 with an average increase of $488.27 \%$ in 2008 and $19.80 \%$ in 2016, (2) Factors which affects problem loan at LPD in District $X$ is internal factor consisting of administrative weakness and weakness of human resource quality and external factor that is debtor factor, (3) The most dominant factor influencing promblem credit is weakness in credit documentation is the most internal factor dominant influence of promblem debts and carelessness of debtor is the dominant external factor affecting problem credit at LPD in District X
\end{abstract}

Keywords : Problem loan, Lembaga Perkeditan Desa

\section{PENDAHULUAN}

Lembaga Perkreditan Desa (LPD) merupakan lembaga keuangan mikro non bank yang dibentuk oleh pemerintah daerah berdasarkan SK No. 8 tahun 2002 sebagai pengganti SK No. 2 tahun 1988. Lembaga ini bergerak dalam bidang keuangan yang berfungsi untuk menghimpun dana 
masyarakat dalam bentuk tabungan maupun simpanan berjangka, yang nantinya akan diedarkan kembali melalui kredit kepada masyarakat setempat.

Keberadaan LPD di Bali pertama kali dilandasi oleh Perda Tingkat I Bali No. 06 Tahun 1986. LPD memiliki beberapa tujuan (Mantra, 1998) sebagai berikut. Pertama, mendorong pembangunan ekonomi masyarakat desa melalui tabungan yang terarah serta penyaluran modal yang efektif. Kedua, memberantas sistem ijon, gadai gelap, dan lain-lain yang bisa disamakan dengan itu di daerah pedesaan. Ketiga, menciptakan pemerataan dan kesempatan kerja bagi warga pedesaan. Keempat, menciptakan daya beli dan melancarkan lalu lintas pembayaran dan pertukaran di desa. Landasan operasional LPD berpijak pada awig-awig desa adat yang mengedepankan ikatan kekeluargaan dan semangat gotong royong antarwarga desa adat. Masyarakat memberikan kepercayaan kepada pihak LPD untuk menjaga sejumlah dana yang telah disimpan, kemudian pihak LPD menempatkan atau menyalurkan dana tersebut kepada debitur yang dilandasi unsur kepercayaan.

Sebelum LPD memberikan kredit kepada calon debitur, terlebih dahulu kreditur harus menentukan calon debitur yang layak. Agar dapat menentukan besarnya jumlah pinjaman yang akan diberikan, kreditur juga harus mengetahui kondisi atau keadaan keuangan calon debitur, dimaksudkan untuk memperkecil risiko kredit. Pemberian kredit mengandung suatu tingkat risiko tertentu dimana ada kemungkinan kredit kurang lancar atau bahkan tidak dapat ditagih. Untuk menghindari atau memperkecil risiko tersebut, maka permohonan kredit harus dianalisis oleh pihak LPD. Menurut Abdullah (2003: 80) prinsip analisis kredit dikenal dengan konsep 5C, yaitu: character, capacity, capital, collateral, condition, dengan dipenuhinya konsep 5C tersebut maka kemungkinan kredit macet dapat diminimalisasikan.
Menurut Dahlan (2001:201) kredit macet atau problem loan adalah kredit yang mengalami kesulitan pelunasan akibat adanya faktor-faktor atau unsur-unsur kesengajaan atau karena kondisi di luar kemampuan debitur. Walaupun analisis kredit telah dilakukan, namun tidak jarang kredit yang telah dikeluarkan mengalami masalah karena debitur tidak mampu menyelesaikan kredit sebagaimana mestinya atau melampaui batas waktu yang telah ditentukan sesuai dengan perjanjian kredit yang telah disepakati bersama sehingga menyebabkan kredit macet.

Berbagai faktor yang diduga sebagai penyebab kredit macet yaitu faktor intern dan faktor ekstern. Faktor intern adalah faktor yang menyebabkan kredit macet dari pihak dalam lembaga keuangan, sedangkan faktor ekstern adalah faktor yang menyebabkan kredit macet yang berasal dari luar lembaga keuangan yaitu dari nasabah atau lingkungan. Suyatno, dkk. (1999: 117) menyatakan, Penyebab kredit macet dilihat dari faktor intern yaitu kegagalan mengelola usaha, kebijakan perkreditan yang kurang menunjang, kelemahan sistem dan prosedur penilaian kredit, pemberian dan pengawasan kredit yang menyimpang dari prosedur. Sedangkan penyebab kredit macet dilihat dari faktor ekstern yaitu lingkungan usaha debitur yang kurang menunjang (jauh dari rumah penduduk dan keramaian, lingkungan yang kotor sehingga tidak ada pembeli), musibah seperti kebakaran, bencana alam, kegagalan mengelola usaha, dan persaingan antara lembaga keuangan.

Berdasarkan data laporan kredit yang diperoleh dari kantor Pembina Lembaga Perkreditan Desa Kabupaten (PLPDK), dari 37 LPD yang ada di Kecamatan $X$ ternyata masih terdapat 23 LPD yang mengalami kredit macet. Adapun besar kredit macet dari tahun 2014 sampai tahun 2016 ditunjukkan pada Tabel 1 berikut. 
Tabel 1. Kredit Macet Tahun 2014-2016

\begin{tabular}{cccc}
\hline Tahun & \multicolumn{2}{c}{ Jumlah Kredit macet (Rp) } & \multicolumn{2}{c}{ Peningkatan (\%) } \\
\cline { 2 - 4 } 2014 & $(\mathrm{Rp})$ & $(\mathrm{Rp})$ & $(\%)$ \\
2015 & 1.694 .358 .000 & - & - \\
2016 & 2.490 .358 .000 & 796.000 .000 & 46,98 \\
\hline
\end{tabular}

Sumber: Laporan Klasifikasi Pinjaman LPD 2014 sampai tahun 2016

Dari data di atas dapat diketahui bahwa masih banyak LPD di Kecamatan X yang mengalami kredit macet. Hal tersebut bisa dilihat dari jumlah kredit macet dari tahun 2014 sampai tahun 2016 terus mengalami peningkatan. Pada tahun 2015 kredit macet meningkat sebesar $\mathrm{Rp}$ 796.000.000 dari tahun 2014 dan pada tahun 2016 jumlah kredit macet juga mengalami peningkatan sebesar Rp 732.724.000 dari tahun 2015. Menurut

\begin{abstract}
Abdullah (2003:84), indikasi terjadinya kredit macet ditandai dengan beberapa hal yaitu semakin lama masa perputaran piutang, meningkatnya rasio hutang, dan menurunnya rasio likuiditas. Menurut Awat (1999: 389), rasio hutang dapat diketahui dengan membandingkan antara total hutang dengan total aktiva yang dimiliki oleh pihak LPD. Berdasarkan hasil perhitungan, maka diperoleh besarnya rasio hutang sebagai berikut.
\end{abstract}

Tabel 2. Gejala Kredit Macet Tahun 2013-2016

\begin{tabular}{crrc}
\hline Tahun & \multicolumn{1}{c}{ Total Hutang (Rp) } & Total Aktiva (Rp) & Rasio Hutang \\
\hline 2013 & 52.014 .811 .000 & 65.182 .865 .000 & $79,80 \%$ \\
2014 & 66.848 .615 .000 & 82.929 .505 .000 & $80,61 \%$ \\
2015 & 89.333 .951 .000 & 108.598 .401 .000 & $82,26 \%$ \\
2016 & 109.084 .871 .000 & 132.154 .611 .000 & $82,54 \%$ \\
\hline
\end{tabular}

Sumber: Rekapitulasi Laporan Keuangan LPD se-Kecamatan X Tahun 2013-2016

Tabel di atas menunjukkan bahwa rasio hutang mengalami peningkatan dari tahun 2013 sampai tahun 2016. Menurut Munawir (2002:239), bagi pihak lembaga keuangan, makin besar rasio hutang berarti akan semakin besar risiko yang ditanggung atas kegagalan yang mungkin terjadi.

Gejala kredit macet pada LPD di Kecamatan $\mathrm{X}$ juga ditunjukkan dengan menurunnya rasio likuiditas dari tahun 2013 sampai tahun 2015. Menurut Suartana, (2009: 56), rasio likuiditas pada LPD bisa diketahui dengan membandingkan antara pinjaman yang diberikan LPD dengan tabungan dan deposito yang dimiliki oleh LPD.

Tabel 3 Gejala Kredit Macet Tahun 2013-2015

\begin{tabular}{ccrc}
\hline Tahun & Pinjaman (Rp) & $\begin{array}{l}\text { Tabungan+Deposito } \\
(\mathrm{Rp})\end{array}$ & Rasio Likuiditas \\
\hline 2013 & 49.475 .583 .000 & 12.686 .573 .000 & $389,98 \%$ \\
2014 & 57.055 .763 .000 & 21.805 .159 .000 & $261,66 \%$ \\
2015 & 73.367 .510 .000 & 28.597 .466 .000 & $256,55 \%$ \\
\hline
\end{tabular}

Sumber: Rekapitulasi Laporan Keuangan LPD se-Kecamatan X Tahun 2013-2015

Tabel 3 di atas menunjukkan bahwa rasio likuiditas mengalami penurunan pada tahun
2013 sampai tahun 2015. Menurunnya rasio likuiditas menunjukkan semakin kecil 
kemampuan LPD untuk memenuhi kewajiban keuangan yang harus segera dipenuhi. Bertitik tolak dari masalah tersebut di atas maka peneliti tertarik untuk melakukan analisis faktor-faktor yang menyebabkan kredit macet pada Lembaga Perkreditan Desa (LPD) di Kecamatan X.

\section{METODE}

Penelitian ini dilakukan di LPD yang ada di Kecamatan $X$ yang mengalami kredit macet dengan pengamatan difokuskan pada kredit macet dan faktor yang menyebabkan kredit macet. Penelitian ini dilakukan untuk memperoleh temuan deskriptif mengenai kredit macet pada LPD di Kecamatan $\mathrm{X}$, mengetahui faktor-faktor yang menyebabkan kredit macet pada LPD di Kecamatan $X$, dan untuk mengetahui faktor yang paling dominan menyebabkan kredit macet pada LPD di Kecamatan X. Sehubungan dengan hal tersebut, maka dalam pelaksanaan penelitian ini akan menggunakan jenis atau bentuk penelitian verifikatif yang digunakan untuk menguji hipotesis yang memakai perhitunganperhitungan statistik yang dilaksanakan melalui pengumpulan data di lapangan (pada nasabah dan pegawai LPD di Kecamatan $X$ yang mengalami kredit macet) dan metode penelitian yang digunakan adalah metode survei. Masri Singarimbun dan Sofian Effendi (1995: 3) mengatakan bahwa metode survei adalah penelitian yang mengambil sampel dari populasi dan menggunakan kuesioner sebagai alat pengumpulan data utama.

Dalam penelitian ini proses penarikan sampel minimal dilakukan dengan teknik simple random sampling melalui dua tahap (two stage cluster sampling) yaitu melakukan random tahap pertama untuk menentukan jumlah LPD yang menjadi sampel wilayah penelitian kemudian melakukan random tahap kedua untuk menentukan jumlah nasabah dan pegawai pada LPD yang menjadi responden.

Pada penelitian ini ada 23 sampling primary unit (SPU) karena di Kecamatan X terdapat 23 LPD yang mengalami kredit macet yang dijadikan SPU. Menurut Nazir
(2004: 314) penarikan sampel secara random dari SPU dilakukan dengan rumus:

$$
f=\frac{m}{M}
$$

Keterangan:

$$
\begin{aligned}
& f=\text { sampel fraction } \\
& m=\text { besar unit sampel } \\
& M=\text { jumlah SPU }
\end{aligned}
$$

Penarikan sampel secara random dari SPU pada penelitian ini menggunakan $\mathrm{f}$ $=43,48 \%$. Gay (dalam Husein, 2005: 79) menyatakan bahwa ukuran sampel fraction untuk penelitian yang menggunakan metode deskriptif korelasional minimal 20\% dari populasi (N). Berdasarkan populasi yang ada, akan dipilih 43,48\% sampel dari jumlah populasi LPD tersebut sehingga jumlah sampel yang diperoleh adalah 10 (sepuluh) LPD.

Tahap selanjutnya menentukan jumlah sampel dari jumlah nasabah dan pegawai LPD. Menurut Slovin (dalam Husein, 2005: 79) untuk menentukan ukuran sampel minimal dalam suatu populasi dilakukan dengan rumus sebagai berikut.

$$
n=\frac{N}{1+N(e)^{2}}
$$

Keterangan:

$$
\begin{aligned}
& \mathrm{n}=\text { ukuran sampel } \\
& \mathrm{N}=\text { ukuran populasi } \\
& \mathrm{e}=\text { persen kelonggaran ketidaktelitian } \\
& \text { karena kesalahan pengambilan } \\
& \text { sampel yang masih dapat } \\
& \text { ditolerir atau diinginkan yaitu } \\
& 10 \% .
\end{aligned}
$$

Berdasarkan rumus di atas maka ditemukan ukuran sampel minimal untuk nasabah sebanyak 74 responden dan untuk pegawai LPD sebanyak 46 responden, sehingga total responden yang digunakan dalam penelitian ini adalah 120 responden. Berdasarkan teknik tersebut maka penentuan ukuran sampel pada masingmasing LPD digunakan ukuran yang proporsional dengan rumus sebagai berikut. 
$\mathrm{n}_{\mathrm{i}}=\frac{N_{i}}{N} \times n$

Keterangan:

$$
\begin{array}{ll}
\mathrm{n}_{\mathrm{i}} & =\text { besarnya sampel di LPD ke-i } \\
\mathrm{Ni} & =\text { besarnya populasi pada LPD } \\
& \text { ke-i } \\
\mathrm{N} \quad & =\text { besarnya populasi secara } \\
\mathrm{n} \quad & \begin{array}{l}
\text { keseluruhan } \\
=\text { besarnya sampel dari populasi }
\end{array}
\end{array}
$$

Pengumpulan data pada penelitian ini menggunakan tiga metode mengumpulan data. Metode pertama yaitu dokumentasi yaitu berupa laporan neracaguna mendapatkan data mengenai klasifikasi pinjaman, jumlah pegawai dan nasabah LPD. Kedua, metode wawancara yang dilakukan dengan pimpinan dan karyawan LPD guna memperoleh data mengenai alas an dimensi-dimensi dari factor internal dan eksternal sebagai penyebab terjadinya kredit macet pada LPD. Ketiga metode angket atau kuesioner yang diberikan kepada nasabah LPD guna memperoleh informasi terakit factor-faktor yang menyebabkan kredit macet pada LPD kecamatan X.

Adapun instrumen yang digunakan dalam penelitian ini telah dilakukan uji validitas dan reliabilitas kepada 30 pegawai LPD pada Kecamatan Y, dan 30 Nasabah LPD di Kecamatan Y. Hasil pengujian validitas item instrumen dari faktor intern dan faktor ekstern dengan menggunakan program SPSS 15.0 menunjukkan bahwa koefisien korelasi Pearson $\left(r_{x y}\right)$ untuk faktor intern berkisar antara 0,400 sampai 0,829 dengan $t_{\text {hitung }}$ berkisar antara 2,3094 sampai 7,8438, untuk faktor ekstern $r_{x y}$-nya berkisar antara 0,479 sampai 0,644 dengan $t_{\text {hitung }}$ berkisar antara 2,8874 sampai 4,4544 sedangkan $t_{0,05} ; 28 ; 1$ sisi $=1,70$. Dari hasil pengujian ini dapat disimpulkan bahwa semua item instrumen baik untuk faktor intern maupun faktor ekstern adalah valid dan dapat digunakan, karena $t_{\text {hitung }}$ lebih besar dari $t_{0,05} ; 28 ; 1$ sisi. Hasil pengujian reliabilitas instrumen dari faktor intern dan faktor ekstern dengan menggunakan program SPSS 15.0 menunjukkan bahwa koefisien korelasi pearson $\left(r_{b}\right)=0,932$ dan $r_{\mathrm{sb}}=0,9648$ untuk faktor intern dan untuk faktor ekstern $r_{b}=0,752$ dan $r_{s b}=0,8584$, sedangkan $r_{0,05 ; 28}=0,306$. Dari hasil pengujian reliabilitas ini dapat disimpulkan bahwa item instrumen baik untuk faktor intern maupun faktor ekstern adalah reliabel, karena nilai hitung $r_{s b}$ lebih besar dari $r_{0,05 ; 28 \text {. }}$

Sesuai dengan perumusan masalah, tujuan penelitian, dan jenis data yang dikumpulkan maka analisis yang digunakan dalam penelitian ini adalah Analisis Deskriptif

Analisis deskriptif digunakan untuk menggambarkan kredit macet pada LPD di Kecamatan $X$ yang bisa diketahui melalui jumlah kredit macet pada masing-masing Lembaga Perkreditan Desa (LPD) di Kecamatan $X$ yang digunakan sebagai tempat penelitian. Dan juga Analisis Faktor digunakan untuk mengetahui faktor-faktor yang menyebabkan atau menjelaskan kredit macet pada LPD di Kecamatan X. Analisis faktor adalah serangkaian prosedur yang digunakan untuk mengurangi dan meringkas data tanpa kehilangan informasi penting dengan beberapa tahapan (Santoso, 2004: 25) yaitu, merumuskan masalah, membuat matrik korelasi, menentukan jumlah faktor, rotasi faktor, dan interpretasi faktor.

\section{HASIL DAN PEMBAHASAN}

Kecamatan X terdiri dari 37 LPD dan 23 diantaranya masih mengalami kredit macet. Fakta tersebut memberikan indikasi bahwa jumlah LPD yang mengalami kredit macet di Kecamatan $X$ adalah sebanyak $62,16 \%$ dari total LPD yang ada. Jumlah kredit macet di LPD Kecamatan $X$ mengalami peningkatan dari Tahun 2014 sampai Tahun 2016. Untuk mengetahui kredit macet pada LPD di Kecamatan X, maka bisa dilihat dari jumlah kredit macet pada masing-masing LPD yang mengalami kredit macet. Adapun jumlah kenaikan kredit macet dari Tahun 2014 sampai Tahun 2016 dan persentase kenaikan serta ratarata kenaikan dari sepuluh LPD yang 
dijadikan tempat penelitian dapat disajikan pada Tabel 4.

Dari tabel 4 dapat dijelaskan bahwa kredit macet pada LPD di Kecamatan X mengalami peningkatan dari tahun 2014 sampai Tahun 2016, walaupun masih ada beberapa LPD yang mengalami penurunan kredit macet. Meningkatnya kredit macet yang dialami oleh LPD di Kecamatan X disebabkan karena semakin besarnya jumlah pinjaman yang dikeluarkan oleh LPD setiap tahunnya dari tahun 2014 sampai Tahun 2016 dan semakin bertambahnya jumlah debitur yang meminjam kredit. Adanya sifat konsumtif debitur yang menggunakan kredit untuk membeli barang mewah yang tidak sebanding dengan kemampuannya untuk membeli dengan penghasilan sendiri dan penyimpangan penggunaan kredit seperti digunakan untuk berjudi juga menyebabkan meningkatnya kredit macet. Selain itu karakter debitur yang sengaja menunda-nunda pembayaran kredit dan bunganya dikarenakan kurang tegasnya sanksi kredit yang ditetapkan oleh LPD juga memicu peningkatan kredit macet, sedangkan penurunan kredit macet pada LPD disebabkan karena sudah adanya upaya penyelamatan kredit sedini mungkin oleh pihak LPD, seperti memberikan peringatan kepada debitur setelah diketahui mulai terlambat membayar, memberikan perpanjangan jangka waktu kredit, penurunan suku bunga untuk lebih meringankan beban debitur, dan upaya penyelamatan terakhir yang sudah dilakukan oleh LPD adalah penyitaan jaminan jika debitur sudah benar-benar tidak mempunyai etikad baik ataupun sudah tidak mampu lagi untuk membayar semua hutang-hutangnya setelah diberikan keringanan kredit.

Tabel 4. Persentase Kenaikan Kredit Macet Pada LPD di Kecamatan X Tahun 2014-2016

\begin{tabular}{|c|c|c|c|c|c|}
\hline \multirow[t]{3}{*}{ No. } & \multirow[t]{3}{*}{$\overline{\text { Nama LPD }}$} & \multicolumn{2}{|c|}{$\begin{array}{l}\text { Kenaikan Kredit Macet dalam } \\
\text { (Rp 000) }\end{array}$} & \multicolumn{2}{|c|}{ Persentase Kenaikan (\%) } \\
\hline & & Tahun 2014 & Tahun 2015 & Tahun 2014 & Tahun 2015 \\
\hline & & ke 2015 & ke 2016 & ke 2015 & ke 2016 \\
\hline 1 & LPD X1 & $(1.200)$ & 22.000 & $(1,20 \%)$ & $22,18 \%$ \\
\hline 2 & LPD X2 & 22.087 & 29.189 & $22,30 \%$ & $24,10 \%$ \\
\hline 3 & LPD X3 & 19.732 & (11.867) & $87,66 \%$ & $(28,09 \%)$ \\
\hline 4 & LPD X4 & 107.884 & 98.068 & $50,76 \%$ & $30,61 \%$ \\
\hline 5 & LPD X5 & $(1.000)$ & $(1.000)$ & $(5,56 \%)$ & $(5,88 \%)$ \\
\hline 6 & LPD X6 & 98.649 & 129.741 & $2.843,73 \%$ & $127,05 \%$ \\
\hline 7 & LPD X7 & 1.560 & 17.065 & $6,15 \%$ & $63,40 \%$ \\
\hline 8 & LPD X8 & 303.949 & 263.128 & $803,84 \%$ & $76,99 \%$ \\
\hline 9 & LPD X9 & 298.524 & (111.441) & $345,98 \%$ & $(28,96 \%)$ \\
\hline \multirow[t]{4}{*}{10} & LPD X10 & 7.925 & (7.512) & $729,07 \%$ & $(83,36 \%)$ \\
\hline & Jumlah & 858.110 & 427.371 & $4882,73 \%$ & $198,04 \%$ \\
\hline & & Rata-rata & persentase & $488,27 \%$ & $19,80 \%$ \\
\hline & & kenaikan & & & \\
\hline
\end{tabular}

Sumber: Data Hasil Penelitian

Untuk menentukan banyaknya faktor yang menyebabkan atau yang mampu menjelaskan kredit macet pada LPD di Kecamatan X, maka dilakukan ekstraksi faktor. Ekstraksi faktor dapat dijelaskan oleh total persentase varians dari masing-masing faktor utama, selain itu untuk menentukan faktor yang menyebabkan kredit macet juga dapat dilakukan dengan memilih faktor atau komponen utama yang memiliki parameter akar karakteristik terkecil (eigenvalue) $>1$. Berdasarkan hasil analisis faktor, maka 
untuk mengetahui faktor yang memiliki eigenvalue $>1$ dapat dilihat pada tabel 5 .

Dari Tabel 5 di atas diketahui ada tiga faktor yang memiliki eigenvalue $>1$ yang terdiri dari dua faktor intern dan satu faktor ekstern. Dua faktor intern yang terbentuk mampu menjelaskan 70,493\% informasi keseluruhan dimensi atau faktor kredit macet atau hanya $29,507 \%$ variasi dimensi atau faktor kredit macet yang tidak tergambarkan oleh faktor intern tersebut, sedangkan satu faktor ekstern (faktor debitur) yang terbentuk mampu menjelaskan $61,645 \%$ informasi keseluruhan dimensi atau faktor kredit macet atau hanya $38,355 \%$ variasi dimensi atau faktor kredit macet yang tidak tergambarkan oleh faktor ekstern tersebut.

Tabel 5. Total Variance Explained

\begin{tabular}{|c|c|c|c|c|c|c|c|}
\hline \multirow[t]{2}{*}{ Faktor } & \multirow[t]{2}{*}{$\begin{array}{l}\text { Comp } \\
\text { o-nent }\end{array}$} & \multicolumn{3}{|c|}{ Initial Eigenvalues } & \multicolumn{3}{|c|}{$\begin{array}{c}\text { Extraction Sums of Squared } \\
\text { Loadings }\end{array}$} \\
\hline & & Total & $\begin{array}{c}\text { \% of } \\
\text { Variance }\end{array}$ & $\begin{array}{c}\text { Cumulative } \\
\%\end{array}$ & Total & $\begin{array}{c}\% \text { of } \\
\text { Variance }\end{array}$ & $\begin{array}{c}\text { Cumulative } \\
\%\end{array}$ \\
\hline \multirow[t]{8}{*}{ Intern } & $X_{1.1}$ & 4,564 & 57,049 & 57,049 & 4,564 & 57,049 & 57,049 \\
\hline & $X_{1.2}$ & 1,075 & 13,444 & 70,493 & 1,075 & 13,444 & 70,493 \\
\hline & $X_{1.3}$ & 0,767 & 9,592 & 80,085 & & & \\
\hline & $X_{1.4}$ & 0,480 & 6,005 & 86,090 & & & \\
\hline & $X_{1.5}$ & 0,473 & 5,912 & 92,002 & & & \\
\hline & $\mathrm{X}_{1.6}$ & 0,284 & 3,552 & 95,553 & & & \\
\hline & $X_{1.7}$ & 0,251 & 3,14 & 98,695 & & & \\
\hline & $\mathrm{X}_{1.8}$ & 0,104 & 1,305 & 100,000 & & & \\
\hline \multirow[t]{4}{*}{ Ekstern } & $X_{2.1}$ & 2,466 & 61,645 & 61,645 & 2,466 & 61,645 & 61,645 \\
\hline & $X_{2.2}$ & 0,770 & 19,261 & 80,906 & & & \\
\hline & $\mathrm{X}_{2.3}$ & 0,579 & 14,481 & 95,387 & & & \\
\hline & $X_{24}$ & 0,185 & 4,613 & 100,000 & & & \\
\hline
\end{tabular}

Sumber: Data Hasil Peneltian

Untuk mengetahui distribusi dimensidimensi yang telah diekstrak kedalam faktor yang telah terbentuk maka dapat dilihat pada Lampiran 1 dan Lampiran 2 pada Tabel rotated component matrix. Dengan demikian faktor yang mampu menjelaskan atau menyebabkan kredit macet pada LPD di Kecamatan $X$ beserta dimendi-dimensi yang termasuk di dalam faktor yang terbentuk dapat dilihat pada Tabel 6 berikut.

Tabel 6. Faktor yang Menyebabkan Kredit Macet

\begin{tabular}{llcc}
\hline & Faktor & Eigenvalue & $\begin{array}{c}\text { Dimensi Kredit } \\
\text { Macet }\end{array}$ \\
\hline Intern & Kelemahan administrasi & 4,564 & $\mathrm{X}_{1.3}$ \\
& & $\mathrm{X}_{1.1}$ \\
& & $\mathrm{X}_{1.4}$ \\
& & $\mathrm{X}_{1.6}$ \\
& & $\mathrm{X}_{1.2}$ \\
& & $\mathrm{X}_{1.8}$ \\
Kelemahan kualitas sumber daya & 1,075 & $\mathrm{X}_{1.7}$ \\
manusia & & $\mathrm{X}_{1.5}$ \\
\hline
\end{tabular}




\begin{tabular}{lll}
\hline Ekstern Debitur & 2,466 & $\mathrm{X}_{2.4}$ \\
& & $\mathrm{X}_{2.3}$ \\
& & $\mathrm{X}_{2.1}$ \\
& & $\mathrm{X}_{2.2}$ \\
\hline
\end{tabular}

Sumber: Data Hasil Penelitian

Dari Tabel di atas dapat dijelaskan faktor-faktor yang menyebabkan kredit macet pada Lembaga Perkreditan Desa (LPD) di Kecamatan X adalah faktor intern dan faktor ekstern. Faktor intern terdiri dari dua faktor yaitu kelemahan administrasi yang terdiri terdiri dari lima dimensi.

Pertama, Kelemahan dalam dokumentasi kredit. Dimensi kelemahan dalam dokumentasi kredit menyebabkan kredit macet pada LPD disebabkan karena lemahnya dokumentasi kredit memberikan indikasi bahwa lemahnya kegiatan administrasi yang ada di LPD. Dokumendokumen kredit yang hilang atau tidak didokumentasi dengan baik akan menyebabkan hilangnya data-data kredit debitur sehingga pihak LPD akan kesulitan dalam melakukan pengecekan jumlah kredit debitur. Hal tersebut memicu munculnya risiko kredit yaitu kredit macet.Kelemahan dalam menganalisa kredit.

Kedua, Dimensi kelemahan dalam menganalisa kredit menyebabkan kredit macet pada LPD disebabkan karena kesalahan dalam melakukan analisis kredit akan memicu munculnya kredit macet. Jika prinsip 5 C (character, capacity, capital, collateral, condition) tidak diterapkan dalam menganalisis permohonan kredit dari debitur, maka kemungkinan besar kredit macet akan terjadi karena belum dilakukan analisis terhadap karakter debitur yang meminjam kredit, belum diketahui modal yang dimiliki oleh debitur untuk mengetahui kemampuan melunasi kredit.

Ketiga, Kurangnya pengawasan kredit. Dimensi kurangnya pengawasan kredit menyebabkan kredit macet pada LPD disebabkan karena apabila tidak dilakukan pengawasan yang baik terhadap penggunaan kredit debitur maka akan mungkin terjadi penyimpangan penggunaan kredit oleh debitur. Hal tersebut tentu saja akan merugikan pihak LPD karena kredit digunakan oleh debitur untuk kegiatan yang tidak penting seperti melunasi hutangnya kepada pihak lain.

Keempat, Kelemahan dalam transaksi jaminan. Dimensi kelemahan dalam transaksi jaminan menyebabkan kredit macet pada LPD disebabkan karena penilaian transaksi jaminan yang tidak hatihati akan merugikan pihak LPD. Seperti keberadaan lokasi jaminan yang belum pasti, nilai jaminan yang diberikan oleh debitur lebih kecil dari jumlah kredit yang diberikan oleh LPD, maka akan merugikan bagi pihak LPD sehingga memicu munculnya kredit macet.

Kelima, Kelemahan dalam prosedur pemberian kredit. Dimensi kelemahan dalam prosedur pemberian kredit menyebabkan kredit macet pada LPD disebabkan karena prosedur pemberian kredit yang tidak melalui prosedur yang berlaku seperti tahapan pengajuan berkas kredit, penyelidikan berkas, wawancara, kunjungan jaminan, keputusan kredit, penandatangan perjanjian kredit, realisasi kredit, dan terakhir penyaluran kredit akan menimbulkan penyalahgunaan kredit, sehingga memicu kredit macet. Tidak adanya pedoman dalam pelaksanaan kebijakan perkreditan yang sehat dan realistik dalam pemutusan pemberian kredit atau pedoman sudah ada namun tidak dijalankan dengan konsisten juga akan menimbulkan masalah kredit.

Faktor internal kedua yaitu kelemahan kualitas sumber daya manusia yang terdiri dari tiga dimensi, Pertama, kecurangan/kenakalan petugas LPD. Dimensi kecurangan/kenakalan petugas LPD menyebabkan kredit macet pada LPD disebabkan karena adanya kecurangan/kenakalan pegawai memberikan indikasi bahwa rendahnya kualitas sumber daya manusia yang ada di 
LPD. Kemungkinan adanya unsur kepentingan pribadi para pengurus LPD dalam memutuskan kreditnya sehingga tidak obyektif lagi dan melanggar prinsipprinsip perkreditan yang sehat, akan menyebabkan masalah kredit macet.

Kedua, kelemahan sumber daya manusia. Dimensi kelemahan sumber daya manusia menyebabkan kredit macet pada LPD disebabkan karena rendahnya pengetahuan dan pengalaman di bidang perkreditan yang dimiliki oleh pegawai LPD serta terbatasnya tenaga profesional di bidang perkreditan yang ada di LPD akan menyebabkan pihak LPD mengalami kesulitan di dalam melakukan penyelamatan kredit macet. Ketidakmampuan petugas kredit LPD dalam melakukan seleksi kredit akan menyebabkan terjadinya pelanggaran yang serius.

Ketiga, Mismanagement pada pengelolaan kredit. Dimensi mismanagement pada pengelolaan kredit menyebabkan kredit macet pada LPD disebabkan karena adanya campur tangan pihak luar dalam pemberian kredit dan kurangnya pemahaman sumber daya manusia yang ada di LPD akan unsur-unsur kredit yang harus diperhatikan seperti adanya risiko kredit, maka akan memicu munculnya risiko kredit macet.

Faktor ekstern, yakni faktor debitur yang terdiri dari empat dimensi. Pertama, kecerobohan debitur. Dimensi kecerobohan debitur menyebabkan kredit macet pada LPD disebabkan karena adanya kecerobohan debitur seperti penyimpangan penggunaan kredit yang dilakukan oleh debitur, tidak cakapnya debitur dalam mengelola uang, kurangnya pengelolaan administrasi pembukuan debitur, dan sifat konsumtif yang dimiliki oleh debitur tentu saja akan menyebabkan kemampuan debitur di dalam melunasi kredit.

Kedua, debitur mengalami musibah. Dimensi debitur mengalami musibah menyebabkan kredit macet pada LPD disebabkan karena seperti kematian yang dialami secara tiba-tiba oleh debitur tentu saja akan menjadi kredit macet bagi LPD, karena debitur sudah tidak sanggup melunasi kreditnya lagi, selain itu musibah yang dialami debitur seperti banjir dan kebakaran juga akan menghambat kemampuan debitur dalam melunasi kredit karena hilangnya harta benda yang dimiliki.

Ketiga, kelemahan karakter debitur. Dimensi kelemahan karakter debitur seperti karakter debitur yang memiliki hutang di banyak tempat selain di LPD menyebabkan kredit macet pada LPD disebabkan karena banyaknya hutang yang ditanggung oleh debitur dibandingkan dengan jumlah penghasilan debitur yang lebih sedikit, maka akan menyebabkan kemampuan debitur dalam melunasi kredit atau sering terjadi keterlambatan debitur dalam membayar bunga dan pinjaman kredit, sehingga nantinya bisa menimbulkan kredit macet.

Keempat, kelemahan kemampuan debitur. Dimensi kelemahan kemampuan debitur menyebabkan kredit macet pada LPD disebabkan karena seperti kegagalan debitur dalam mengelola usaha, pekerjaan debitur yang tidak tetap, serta kurangnya pengetahuan dan pengalaman yang dimiliki debitur akan menyebabkan kemampuan debitur dalam memperoleh penghasilan untuk membiayai kebutuhan hidup dan melunasi kredit di LPD.

Berdasarkan pengujian hipotesis konseptual, untuk menentukan dimensi atau faktor kredit macet yang paling mendominasi atau dominan pada faktor atau komponen utama maka akan digunakan parameter koefisien varimax rotation dari dimensi atau faktor kredit macet yang paling mendekati +1 atau mendekati -1 . Nilai yang mendekati 1 biasanya diwakili oleh nilai 0,5 sedangkan nilai yang mendekati -1 biasanya diwakili oleh nilai $-0,5$. Dari hasil rotasi terhadap faktor matriks pada Tabel 4.4 (lihat varimax rotation), maka faktor yang paling mendominasi pada ketiga komponen utama yang terbentuk, yaitu untuk factor internal Dari kedua faktor dominan yaitu kelemahan dalam dokumentasi kredit dan kecurangan/kenakalan petugas LPD, maka faktor intern yang paling dominan 
menyebabkan kredit macet pada LPD di Kecamatan $X$ adalah kelemahan dalam dokumentasi kredit karena nilai varimax rotation-nya lebih besar yaitu 0,903.

Faktor Ekstern (Faktor 3, kecerobohan debitur), dengan nilai varimax rotation 0,910. Artinya kejelasan asosiasi dari dimensi kredit macet, kecerobohan debitur yang mendominasi pada faktor 3 sebesar 0,910. Dimensi kecerobohan debitur paling dominan menyebabkan kredit macet pada LPD dari faktor ekstern disebabkan karena adanya kecerobohan debitur seperti penyimpangan penggunaan kredit yang dilakukan oleh debitur, tidak cakapnya debitur dalam mengelola uang, kurangnya pengelolaan administrasi pembukuan debitur, dan sifat konsumtif yang dimiliki oleh debitur tentu saja akan menyebabkan kemampuan debitur di dalam melunasi kredit karena sifat boros debitur yang tidak bisa mengatur keuangan dengan baik. Jika debitur terus mengalami hambatan di dalam melunasi kredit, maka akan menjadi risiko kredit bagi pihak LPD, dan apabila debitur sudah tidak lagi mampu melunasi kredit yang dipinjamnya maka akan memicu munculnya kredit macet LPD.

Secara lebih rinci hasil ringkasan rotasi dari matriks faktor yang memuat nilai varimax rotation, nilai communalities (variasi bersama yang dijelaskan oleh dimensi atau faktor kredit macet terhadap keseluruhan faktor atau komponen utama) dapat dilihat pada Tabel 7 berikut.

Tabel 7. Matriks Rotasi Hasil Analisis Faktor

\begin{tabular}{lrrrrc}
\hline \multirow{2}{*}{ Dimensi/faktor kredit macet } & \multicolumn{3}{c}{ Varimax Rotation } & Communalities \\
\cline { 2 - 3 } Kelemahan dalam menganalisa kredit & \multicolumn{2}{c}{2} & 3 & \\
Kelemahan dalam prosedur pemberian kredit & 0,871 & 0,169 & - & 0,787 \\
Kelemahan dalam dokumentasi kredit & 0,903 & 0,428 & - & 0,600 \\
Kurangnya pengawasan kredit & 0,682 & 0,521 & - & 0,828 \\
Mismanagement pada pengelolaan kredit & 0,232 & 0,662 & - & 0,736 \\
Kelemahan dalam transaksi jaminan & 0,677 & 0,620 & - & 0,492 \\
Kelemahan sumber daya manusia & 0,276 & 0,728 & - & 0,642 \\
Kecurangan/kenakalan petugas LPD & 0,092 & 0,860 & - & 0,748 \\
Kelemahan karakter debitur & - & - & 0,724 & 0,524 \\
Kelemahan kemampuan debitur & - & - & 0,669 & 0,447 \\
Debitur mengalami musibah & - & - & 0,817 & 0,668 \\
Kecerobohan debitur & - & - & 0,910 & 0,827 \\
\hline
\end{tabular}

Sumber: Data Hasil Penelitian

Kredit macet pada LPD di Kecamatan $X$ mengalami kenaikan dari tahun 2014 sampai tahun 2016 dengan rata-rata persentase kenaikan sebesar 488,27\% pada tahun 2015 dan 19,80\% pada tahun 2016. Kredit macet pada LPD di Kecamatan $X$ dipengaruhi oleh dua faktor yaitu (1) faktor intern dan (2) faktor ekstern. Faktor intern disebabkan karena kelemahan administrasi yang terdiri dari kelemahan dalam dokumentasi kredit, kelemahan dalam menganalisa kredit, kurangnya pengawasan kredit, kelemahan dalam transaksi jaminan, dan kelemahan dalam prosedur pemberian kredit, serta kelemahan kualitas sumber daya manusia yang terdiri dari kecurangan/kenakalan petugas LPD, kelemahan sumber daya manusia, dan mismanagement pada pengelolaan kredit. Faktor ekstern disebabkan karena faktor debitur yang terdiri dari kecerobohan debitur, debitur mengalami musibah, kelemahan karakter debitur, dan kelemahan kemampuan debitur. Dari kedua faktor tersebut, faktor yang paling dominan menyebabkan kredit macet pada LPD di Kecamatan $X$ dilihat dari dari faktor intern adalah kelemahan dalam dokumentasi 
kredit, sedangkan dilihat dari faktor ekstern, maka faktor yang paling dominan menyebabkan kredit macet pada LPD di Kecamatan $\mathrm{X}$ adalah faktor kecerobohan debitur.

Faktor intern dan faktor ekstern yang menyebabkan kredit macet pada LPD di Kecamatan $X$ sesuai dengan pendapat yang dinyatakan oleh Suyatno,dkk (1999), Kasmir (2001), Perbarindo (2005), dan Mudrajat (2003) yang menyatakan bahwa faktor intern dan faktor ekstern adalah faktor-faktor yang menyebabkan kredit macet. Faktor intern dan Faktor ekstern yang menyebabkan kredit macet pada LPD di Kecamatan $X$ juga sesuai dengan hasil penelitian sebelumnya yang relevan, hanya saja pada penelitian sekarang terdapat penambahan dimensi kredit macet seperti mismanagement pada pengelolaan kredit, kelemahan sumber daya manusia, dan kecurangan/kenakalan petugas LPD dari faktor intern, serta penambahan dimensi kelemahan karakter debitur dari faktor ekstern yang tidak dibahas pada penelitian sebelumnya.

Meskipun hasil penelitian yang diperoleh mengenai faktor-faktor yang menyebabkan kredit macet sesuai dengan hasil penelitian sebelumnya yaitu faktor intern dan faktor ekstern, tetapi dalam hal menentukan faktor yang paling dominan menyebabkan kredit macet terdapat perbedaan. Hal ini disebabkan karena lokasi penelitian yang berbeda sehingga situasi, karakter debitur dan pegawai LPD juga berbeda-beda. Jenis lembaga keuangan serta metode analisis data yang berbeda dari penelitian sebelumnya juga dapat menjadi penyebab perbedaan hasil penelitian dalam menentukan faktor yang paling dominan menyebabkan kredit macet pada LPD di Kecamatan $X$ baik dari faktor intern maupun faktor yang paling dominan dari faktor ekstern.

\section{SIMPULAN}

Berdasarkan hasil analisis data dan pembahasan, maka dapat ditarik simpulan bahwa kredit macet pada Lembaga Perkreditan Desa (LPD) di Kecamatan X mengalami kenaikan dari Tahun 2014 sampai tahun 2016 dengan rata-rata kenaikan 488,27\% pada tahun 2015 dan $19,80 \%$ pada tahun 2016 . Terdapat dua faktor yang menyebabkan kredit macet pada LPD di Kecamatan X, yaitu faktor internal dan Eksternal. Faktor internal meliputi yang terdiri dari kelemahan administrasi dengan lima dimensi yaitu: kelemahan dalam dokumentasi kredit, kelemahan dalam menganalisa kredit, kurangnya pengawasan kredit, kelemahan dalam transaksi jaminan, serta kelemahan dalam prosedur pemberian kredit, dan kelemahan kualitas sumber daya manusia dengan tiga dimensi yaitu: kecurangan/kenakalan petugas LPD, kelemahan sumber daya manusia, serta mismanagement pada pengelolaan kredit. Sedangkan factor esnternal terdiri dari empat dimensi yaitu: kecerobohan debitur, debitur mengalami musibah, kelemahan karakter debitur, dan kelemahan kemampuan debitur.

Berdasarkan hasil analisis ditemukan bahwa faktor yang paling dominan menyebabkan kredit macet pada LPD di Kecamatan $X$ adalah faktor kelemahan dalam dokumentasi kredit merupakan faktor intern yang paling dominan menyebabkan kredit macet pada LPD di Kecamatan X, dan (2) faktor kecerobohan debitur merupakan faktor ekstern yang paling dominan menyebabkan kredit macet pada LPD di Kecamatan X.

\section{DAFTAR PUSTAKA}

Abdullah, Faisal. 2003. Manajemen Perbankan. Malang: UMM.

Awat, Napa J. 1999. Manajemen Keuangan. Jakarta: Gramedia.

Husein, Umar. 2005. Metode Penelitian untuk Skripsi dan Tesis Bisnis. Jakarta: PT Raja Grafindo Persada

Kasmir. 2001. Bank dan Lembaga Keuangan Lainnya. Jakarta: PT. Raja Grafindo.

Mudrajat, Kuncoro. 2003. Ekonomi Pembangunan Teori, Masalah, dan 
Kebijakan. Edisi ketiga. Yogyakarta: Unit Penerbitan dan Percetakan (UPP) AMP YKPN.

Munawir. 2002. Analisa Laporan Keuangan. Yogyakarta: LIBERTY.

Nazir, Moh. 2004. Metode Penelitian. Jakarta: Ghalia Indonesia.

Perbarindo. 2005. Strategi Penyelesaian Kredit Bermasalah. Bali: Tim Pelatih Perbarindo.

Santoso, Singgih . 2004. SPSS Versi 11.5. Mengatasi Berbagai Masalah Statistik Dengan SPSS, Edisi Kelima. Jakarta: PT. Elex Media Komputindo.

Siamat, Dahlan. 2001. Manajemen Lembaga Keuangan. Edisi ketiga. Jakarta: Lembaga Penerbit Fakultas ekonomi Universitas Indonesia.

Suartana, Wayan. 2009. Arsitektur Pengelolaan Risiko Pada Lembaga Perkreditan Desa (LPD). Denpasar: Udayana University Press.

Suyatno, Thomas, H.A. Chalik, Tinon Yunianti Ananda, Djuhaepah. T. Marala. 1999. Dasar-Dasar Perkreditan. Jakarta: PT. Gramedia Pustaka Utama. 